$<$ Article $>$

\title{
The Use of 'Macro' Legal Analysis in the Understanding and Development of Global Environmental Governance
}

\author{
Stephen J. Turner*
}

\begin{abstract}
This article examines the manner in which 'macro' legal analysis can potentially assist in overcoming some of the issues that are faced in the understanding and development of global environmental governance (GEG). It argues that the analysis of law through separate and distinct disciplines such as environmental law, trade law, corporate law, and human rights law, results in what this article refers to as 'micro' legal analysis. As such, it contends that this can have the effect of creating obstacles in the development of coherent and effective legal and policy choices related to the protection of the environment. It illustrates these arguments with examples of practical problems that have arisen from the separation of legal issues in practice and provides the theoretical underpinnings, based on the critique of international lawyers, for the application of 'macro' legal analysis. In other words, it argues for a form of analysis that would consider the entire range of relevant legal disciplines in a unitary process. It then provides a methodology for the development and application of 'macro' legal analysis in relation to environmental issues. Finally, it considers the potential that this approach could have within the field of GEG and comments on the implications that it could have on the way that lawyers are trained in the future.
\end{abstract}

Keywords: Global environmental governance; Macro legal analysis; Micro legal analysis; International environmental law; Non-state actors, Legal training

\section{INTRODUCTION}

\footnotetext{
* Lincoln University, Law School, Lincoln (United Kingdom).

Email: stturner@lincoln.ac.uk

The author would like to thank Prof. Duncan French, Dr Christy Shucksmith, two anonymous reviewers and the editorial staff at TEL for helpful comments on earlier drafts of this article.
} 
There has long been concern with the progress made in the field of international environmental law (IEL) ${ }^{1}$ and with global environmental governance (GEG) generally. ${ }^{2}$ As the international community examines this progress, there are questions relating to the adequacy of the types of legal analyses that are used to understand the way that law and governance can affect outcomes for the environment. These questions are important, as the form of legal analysis that is carried out is crucial to the process of understanding the strengths and weaknesses of existing approaches to law and governance and can play a decisive part in the way in which GEG is developed in the future.

When considering GEG lawyers are faced with a wide range of issues to contend with. Naturally there is considerable focus upon the potential and limitations of IEL. However, by the same token, there has been an increased awareness of the effects that other areas of law have upon the environment; for example, company law, trade law, banking law, investment law, human rights law, and constitutional law can all have significant, albeit indirect impacts upon it. ${ }^{3}$

${ }^{1}$ D. Bodansky, The Art and Craft of International Environmental Law, (Harvard University Press, 2011), at p. 35 .

${ }^{2}$ F. Biermann, P. Pattberg \& F. Zelli, ‘Global Climate Governance Beyond 2012: An Introduction', in F. Biermann, P. Pattberg \& F. Zelli (eds.), Global Climate Governance Beyond 2012: - Architecture, Agency and Adaptation (Cambridge University Press, 2010), pp. 1-12, at 11.

${ }^{3}$ See, e.g., K. Tienhaara, The Expropriation of Environmental Governance: Protecting Foreign Investors at the Expense of Public Policy (Cambridge University Press, 2009); B. Sjåfell \& B. J. Richardson (eds), Company Law and Sustainability: Legal Barriers and Opportunities (Cambridge University Press, 2014); E. Daly \& J. May, Global Environmental Constitutionalism (Cambridge University Press, 2014); S.J. Turner, A Substantive Environmental Right: An Examination of the Legal Obligations of Decision-Makers Towards the Environment (Kluwer Law International, 2009); D.C. Esty, Greening the GATT: Trade, the Environment, and the Future (Institute for International Economics, 1994). 
At the same time, there has been a renewed focus on the fragmented manner in which institutions have developed at the international level and the manner in which they sometimes create, or respond to, competing priorities within the international community. ${ }^{4}$ Additionally, the future of existing international institutions that are charged with administering or developing environmental law treaties has been questioned. For example, the future of the newly founded United Nations Environment Assembly (UNEA) raises significant issues related to the role and authority that it will ultimately assume. ${ }^{5}$ Alongside these considerations, some sections of civil society have been active in developing alternative methods of governance that include non-legally binding environmental controls, such as certification schemes and quality standards. ${ }^{6}$

This fluid range of what are sometimes disconnected factors, means that it can be difficult to define with precision the constituent elements of 'global environmental governance'. Consequently, it can be hard to identify effective and efficient strategies for reform. Amongst other challenges, lawyers working in this field face the task of creating coherent and balanced strategies for the development of the legal and institutional architecture that is required to meet the exigencies of environmental governance in the future. However, the diverse range of factors that are integral to GEG, as identified above, raises questions about the type of legal examination that has sufficient breadth and clarity to produce such strategies.

Accordingly, this article inquires into the type of legal analysis that is required both to evaluate existing GEG and to develop coherent strategies for its further development.

\footnotetext{
${ }^{4}$ M. Koskenniemi, The Politics of International Law (Hart, 2011), pp. 334-7.

${ }^{5}$ B.H. Desai, International Environmental Governance: Towards UNEPO (Brill-Nijhoff, 2014), p. 18.

${ }^{6}$ J.F. Green, Rethinking Private Authority: Agents and Entrepreneurs in Global Environmental

Governance (Princeton University Press, 2014), pp. 37-8.
} 
It argues that existing approaches to legal analysis within the field tend to correspond with the type of legal analysis prevalent in other fields of legal scholarship, which are usually characterized by the examination of very specific aspects of law, and which this article refers to as 'micro' legal analysis. This approach often only provides part of the picture where GEG is concerned. This article therefore considers the merits of using 'macro' legal analysis to complement existing approaches, in particular to assist in providing a broader, synoptic understanding of the law, institutions and initiatives that can be said to constitute GEG. It argues that such an approach would aid in providing coherent reform options by taking into account the multifarious ranges of law and quasi-legal initiatives that can affect outcomes for the environment.

The article is structured as follows. It prefaces the central analysis with a discussion of the use of the terms 'global environmental governance', 'micro' legal analysis and 'macro' legal analysis. From that foundation it summarizes the ways in which both 'state' and 'non-state' actors have generally compartmentalized the component parts of GEG, and how this corresponds to the approach that lawyers often adopt in their analyses of the issues. As such, it considers the potential negative effects of adopting an analysis that does not take into account all of the relevant legal and quasi-legal components that can affect the outcomes of GEG. This leads to the central tenet of the article, which provides theoretical arguments in support of the development of 'macro' legal analysis in this context, and outlines a methodology for its use. The article concludes by commenting on some of the challenges related to the use of 'macro' legal analysis in the field of GEG and the potential implications it has for training lawyers in the future.

\section{USE OF TERMINOLOGY}

The term 'global environmental governance' is extremely widely used and has been coopted to serve a variety of purposes. Conversely, the terms 'macro' and 'micro' legal analysis are extremely rarely used within the context of environmental law or GEG. This section will consider these terms in turn to clarify their meaning and the manner in which they are used in this article. 


\section{1 'Global Environmental Governance'}

The term 'governance' is thought to be derived from the Greek word kubernan, which can be translated to mean 'pilot', 'steer', or 'direct' and which was translated into Latin as gubernare. ${ }^{7}$ Part of the complexity of the term can be inferred from the way in which it has been used since the 1990s. For example, it is used in different academic disciplines including economics, ${ }^{8}$ political science, ${ }^{9}$ business and finance, ${ }^{10}$ as well as law. ${ }^{11}$ Moreover, it is also used to describe certain forms of regulatory oversight within industry; thus the terms 'corporate" ${ }^{12}$ and 'financial' ${ }^{13}$ governance have become part of common parlance within the commercial world.

In the field of environmental protection, the terms 'environmental governance' and 'global environmental governance' are used for a variety of purposes, which also leads to ambiguity. ${ }^{14}$ The term 'global environmental governance' has been used to describe the different regimes of IEL along with the functioning of associated international

${ }^{7}$ D. Levi-Faur, 'From "Big Government" to "Big Governance"?', in D. Levi-Faur (ed.), The Oxford Handbook of Governance (Oxford University Press, 2012), pp. 3-18, at 5.

${ }^{8}$ E.g. S. Park \& J.R. Strand (eds), Global Economic Governance and the Development Practices of the Multilateral Development Banks (Routledge, 2016); R. Eccleston, The Dynamics of Global Economic Governance: The Financial Crisis, the OECD, and the Politics of International Tax Cooperation (Edward Elgar, 2014).

${ }^{9}$ E.g. J.P. Voß \& R. Freeman (eds) Knowing Governance: The Epistemic Construction of Political Order (Palgrave Macmillan, 2015).

${ }^{10}$ E.g. E. Avgouleas, Governance of Global Financial Markets (Cambridge University Press, 2012).

${ }^{11}$ E.g. G. de Búrca, C. Kilpatrick \& J. Scott (eds), Critical Legal Perspectives on Global Governance (Hart, 2013).

${ }^{12}$ E.g. J. Solomon, Corporate Governance and Accountability (Wiley, 2013).

${ }^{13}$ G.R.D. Underhill \& X. Zhang (eds), International Financial Governance Under Stress: Global Structures Versus National Imperatives (Cambridge University Press, 2007).

${ }^{14}$ L. Kotzé, Global Environmental Governance: Law and Regulation for the $21^{\text {st }}$ Century (Edward Elgar, 2012). 
institutions including those of the United Nations (UN). ${ }^{15}$ However, it has also been used in a broader sense to encompass the analysis of transnational regimes ${ }^{16}$ that include non-legally binding rules designed by non-state actors alone or in partnership with state actors with the purpose of achieving specific standards of environmental protection. $^{17}$

With regard to the review of existing structures, the term 'global environmental governance' is often used when discussing potential reform of UN institutions. ${ }^{18}$ As such, it has been viewed as a term linked with change and one that can be used by policy makers when considering potential solutions for global environmental problems. ${ }^{19}$ Levi-Faur states that the concept of 'governance' can be approached as a structure, a process, a mechanism, a strategy, and possibly in other ways too; ${ }^{20}$ therefore, it is extremely difficult to provide a single definition. ${ }^{21}$ Additionally, it is now common for the rules and institutional arrangements that relate to specific sectors of environmental protection to be discussed in terms of 'governance'. For example, the term 'governance'

\footnotetext{
${ }^{15}$ E.g. J.G. Speth \& P.M. Haas, Global Environmental Governance (Pearson-Longman, 2006).

${ }^{16}$ P.H. Pattberg, 'Transnational Environmental Regimes', in F. Biermann \& P. Pattberg (eds), Global Environmental Governance Reconsidered (The MIT Press, 2012), pp. 97-122.

${ }^{17}$ G. Winter, 'Introduction', in G. Winter (ed.), Multilevel Governance of Global Environmental

Change: Perspectives from Science, Sociology and the Law, (Cambridge University Press, 2006), p.

12; P.M. Haas, S. Andresen \& N. Kanie, 'Introduction: Pluralistic Actor Configurations and Global Environmental Governance: Best and Worst Practices for Improving Environmental Governance', in N. Kanie, S. Andresen \& P.M. Haas (eds), Improving Global Environmental Governance: Best Practices for Architecture and Agency (Routledge, 2014), pp 1-30.

${ }^{18}$ Desai, n. 5 above, p. 91.

${ }^{19}$ F. Biermann \& P. Pattberg, 'Global Environmental Governance Revisited', in Biermann \& Pattberg (eds), n.16 above, pp. 1-24, at 4 .

${ }^{20}$ Levi-Faur, n. 7 above, p. 8.

${ }^{21}$ For an extensive analysis of definitional issues see Kotzé, n.14 above.
} 
is now commonly prefixed by the words 'earth', ${ }^{22}$ 'forest', ${ }^{23}$ 'climate', ${ }^{24}$ 'groundwater', 25 'fisheries', ${ }^{26}$ 'biodiversity', ${ }^{27}$ 'energy', ${ }^{28}$ and 'ocean', ${ }^{29}$ amongst others.

This article does not put forward a single definition of GEG but provides an explanation of the way that it is used for the purposes of this discussion. As such, it uses the term in its broadest sense to embrace three components. Primarily, it refers to the statecentred systems of national and international law that relate directly to environmental protection, that is, 'environmental law' and 'international environmental law' respectively. Secondarily, it refers to those state-centred systems of national and international law which are not primarily directed towards the protection of the environment but which nonetheless have an impact upon it. Finally, it includes nonlegally binding regulatory initiatives by non-state actors (sometimes in partnership with state actors) that develop norms and practices with a view to protecting the environment, which individuals, businesses and communities may consider that they are obliged to comply with for a variety of reasons.

${ }^{22}$ K. Bosselman, Earth Governance: Trusteeship of the Global Commons (Edward Elgar, 2015).

${ }^{23}$ S. Ongolo, 'On the Banality of Forest Governance Fragmentation: Exploring "Gecko Politics" as a Bureaucratic Behaviour in Limited Statehood' (2015) 53 Forest Policy \& Economics, pp.12-20.

${ }^{24}$ H. van Asselt, The Fragmentation of Global Climate Governance (Edward Elgar, 2014).

${ }^{25}$ K.I. Conti \& J. Gupta, 'Protected by Pluralism? Grappling with Multiple Legal Frameworks in Groundwater Governance’ (2014) Current Opinion in Environmental Sustainability, pp. 1139-47.

${ }^{26}$ X. Basurto \& M. Nenadovic, ‘A Systematic Approach to Studying Fisheries Governance’ (2012)

3(2) Global Policy, pp. 222-30.

${ }^{27}$ M. Daccache, 'Questioning Biodiversity Governance through its Articulations' (2013) 18(1) Science, Technology \& Society, pp. 51-62.

${ }^{28}$ E.g. R. Leal-Arcas, A. Filis \& E.S. Abu Ghosh, International Energy Governance: Selected Legal Issues (Edward Elgar, 2014); A. Goldthau \& J. Martin Witte (eds), Global Energy Governance: The New Rules of the Game (Brookings Institution Press, 2010).

${ }^{29}$ R. Kundis Craig, 'Ocean Governance for the $21^{\text {st }}$ century: Making Marine Zoning Climate Change Adaptable' (2012) 36(2) Harvard Environmental Law Review, pp. 305-50. 


\section{2. 'Micro' and 'Macro' Legal Analysis}

There have only been scant references to the terms 'micro' and 'macro' legal (or level) analysis within the context of environmental law and GEG. The few references that are found tend to be highly context-specific and do not correspond to an overall theory or to the type of approach that is discussed in this article. For example, Abraham refers to 'macro' legal analysis within the context of a specific report relating to environmental jurisprudence in India. ${ }^{30}$ Also Fisher, writing in relation to water governance, refers to 'macro' legal systems as the 'statements of value, objective, outcome, or principles', 31 on the one hand, and 'micro' legal systems, as the 'standards for individual conduct, behaviour or decision-making, ${ }^{32}$ on the other.

References to 'micro' and 'macro' forms of legal analysis appear to be most common within comparative legal research. In that context, the comparison of entire legal systems ('macro' level analysis or 'macro' comparison) on the one hand can be distinguished from the comparison of aspects of legal systems, such as individual pieces of legislation ('micro' level analysis or 'micro' comparison) on the other. ${ }^{33}$ The terms have also been used within the context of the analysis of legal cultures, where the 'micro' level might refer to a local court or prosecutor's office and the 'macro' level to

\footnotetext{
${ }^{30}$ C.M. Abraham, Environmental Jurisprudence in India (Kluwer Law International, 1999), p. 74.

${ }^{31}$ D.E. Fisher, ‘A Jurisprudential model for Sustainable Water Resources Governance', in M. Kidd, L.

Ferris, T. Murombo \& A. Iza (eds), Water Security and the Law: Towards Sustainability (Edward
}

Elgar, 2014), pp. 139-66, at 139.

${ }^{32}$ Ibid.

${ }^{33}$ M.M. Siems, Comparative Law (Cambridge University Press, 2014), p. 14; P. de Cruz, Comparative Law in a Changing World (Routledge-Cavendish, 2007); K. Zweigert \& H. Kötz (Translated by T. Weir), An Introduction to Comparative Law (Oxford Univesity Press, 1998), p. 4; M.M. Siems, 'Legal Originality' (2008) 28(1) Oxford Journal of Legal Studies, pp. 147-64 at152ff; O. Granstrand (ed.), Economics, Law and Intellectual Property: Seeking Strategies for Research, (Springer, 2013), p. 539. 
common law traditions as applied in different nations. ${ }^{34}$ Another example relates to international investment law, where it has been used to denote the distinction between systemic 'micro' and 'macro' legal cultural issues. ${ }^{35}$ What is clear, is that these terms have helped linguistically to relativize the scope and depth of legal analysis in relation to a range of subject matter. As such they have proven to be useful and highly adaptable.

For the comparative legal scholar, 'macro' legal analysis often involves discovering and analyzing relationships between laws in different jurisdictions. ${ }^{36}$ However, this article uses the term 'macro' legal analysis to describe the process of discovering and analyzing the full range of laws, legal institutions and quasi-legal initiatives that have an influence upon environmental outcomes, with a view to understanding those components in their entirety (see section 4 below). Therefore, in this context a distinction exists between types of analysis that focus on individual legal regimes ('micro' legal analysis) and those which take into account the aggregate of the legal and quasi-legal components of GEG ('macro' legal analysis).

This article argues that as 'macro' legal analysis entails the consideration of a range of different areas of law and associated institutions it assists in building a broader understanding of the causes of environmental degradation from a legal standpoint. As such, it has the potential to place a fresh perspective on some of the 'root causes' or 'drivers' of environmental degradation that in themselves are ensconced within legal regimes. ${ }^{37}$ By studying the effect of a range of different legal regimes operating in unison it is possible to understand the ways in which they affect, support, or contradict each other and in some instances simply cancel each other out. To explain the backdrop

\footnotetext{
${ }^{34}$ D. Nelken, 'Using the Concept of Legal Culture' (2004) 29 Australian Journal of Legal Philosophy, pp. 1-28, at 3-4.

${ }^{35}$ C.B. Picker, 'International Investment Law: Some Legal Cultural Insights' ${ }_{2}$ in L.E. Trakman \& N. A Ranieri (eds), Regionalism in International Investment Law (Oxford University Press, 2013), pp. 2758 , at 33

${ }^{36}$ C. Enright, Legal Technique (The Federation Press, 2002), p. 347.

${ }^{37}$ Bodansky, n.1 above, p. 10; Stephen J. Turner, A Global Environmental Right (Routledge, 2014), pp. $67-8$.
} 
against which this argument must be appreciated, the next section discusses why established approaches to our understanding of the law are largely based on 'micro' legal analyses and how that colours our understanding of GEG and its potential development.

\section{THE COMPARTMENTALIZATION OF LAW AND LEGAL ANALYSIS}

This section interrogates the compartmentalization that has occurred within legal practice, national law, public international law, IEL and GEG generally. It identifies the relationship between legal compartmentalization and legal analysis and questions some of the prevailing assumptions in relation to the way that we understand, consider and develop legal analysis as an input towards strategies for the future of GEG.

Firstly, at the national level, law is compartmentalized into different categories such as property law, corporate law, tax law, constitutional law, and criminal law. This subjectspecific approach is also reflected in the specialized nature of the courts and institutions that handle legal issues both in the public and private law arenas. Although there was a time when legal practitioners could be expected to have the skills and capacity to deal with a wide variety of different types of legal problems, ${ }^{38}$ the current culture demands that they specialize. ${ }^{39}$ This has proved effective as it allows lawyers to focus on specific areas of law to meet the individual needs of their clients. It could be said that Ricardo's theory of comparative advantage is borne out within the legal sector. ${ }^{40}$

\footnotetext{
${ }^{38}$ W.E. Burger, 'The Special Skills of Advocacy: Are Specialized Training and Certification of Advocates Essential to Our System of Justice?' (1973) 42 Fordham Law Review, pp. 227-42, at 231.

${ }^{39}$ R. Moorhead, 'Lawyer Specialisation: Managing the Professional Paradox' (2008) 32(2) Law \& Policy, pp. 226-59; M.H. Khan \& L. Davidson Kahn, 'Specialization in Criminal Law' (1977) 41(1) Law and Contemporary Problems, pp. 252-92.

${ }^{40}$ D. Ricardo, The Principles of Political Economy and Taxation (Dover Publications, 2004) (originally published1817).
} 
Secondly, the legal compartmentalization that has occurred at the national level is mirrored in public international law. Public international law is not only treated as a separate discipline to national law but is made up of numerous compartmentalized subdisciplines. ${ }^{41}$ It has evolved through different institutions being tasked to achieve discrete goals relating to aspects of concern to the international community. As Jouannet states, these sub-disciplines exist:

to achieve specific economic and social objectives designed to satisfy isolated or restricted needs and to accomplish precise material results; so much so that the international legal order naturally tends to hive off into subsystems so as to better regulate the specific characteristics of the various social and economic activities that are now ascribed to it. ${ }^{42}$

Examples of these subsystems include the World Trade Organization (WTO) with the objective of developing 'free trade', the United Nations Environment Programme (UNEP) and the UNEA charged with the coordination of the work of the international community in relation to the environment, and the United Nations Development Programme (UNDP) which primarily has the objective of assisting with the coordination of social and economic development of developing countries. As each of these branches of international governance has developed its own specific objectives and sub-sets of international law, commentators have made the point that this sometimes leads to competing priorities between international institutions. ${ }^{43}$

\footnotetext{
${ }^{41}$ E. Jouannet (Translated by C. Sutcliffe), The Liberal-Welfarist Law of Nations: A History of International Law (Cambridge University Press, 2012), p. 264.

${ }^{42}$ Ibid.

${ }^{43}$ International Law Commission (ILC), Fragmentation of International Law: Difficulties Arising from the Diversification and Expansion of International Law - Report of the Study Group of the
} International Law Commission, Finalized by Martti Koskenniemi, UN Doc. A/CN.4/L.682 (13 Apr. 2006); Koskenniemi, n. 4 above, pp. 334-7; C.P. Carlane, 'Good Climate Governance: Only a Fragmented System of International Law Away?' (2008) 30(4) Law \& Policy, pp. 450-80, at 457; D. Shelton, 'Legitimate and Necessary: Adjudicating Human Rights Violations Related to Activities Causing Environmental Harm or Risk' (2015) 6(2) Journal of Human Rights and the Environment, pp. 139-55. 
A good example of the manner in which this can impact GEG is found in the General Agreement on Tariffs and Trade (GATT). ${ }^{44}$ It includes provisions designed to discourage protectionism through trade barriers. Potentially, environmental laws can amount to trade barriers and therefore under the GATT, states are required to ensure that any environmental measures do not fall foul of the 'trade disciplines'. ${ }^{45}$ However, whilst the GATT is designed to achieve the objective of trade liberalization, it has not been designed to concurrently ensure that specific environmental standards are achieved and maintained by its members. In his 1994 book Greening the GATT, Daniel Esty made the observation that:

[f] undamentally, the GATT is asymmetrical; its rules only permit a decision that particular environmental standards 'excessively' intrude on trade prerogatives. The GATT provides no comparable process for declaring a nation's economic activities (and related trade) to be environmentally 'inadequate' - and therefore an unfair basis for trade. Thus, the GATT fails to satisfactorily accommodate environmental protection in defining the ground rules for trade. ${ }^{46}$

Whilst clearly efforts have been made by the WTO to take environmental issues into account over the last two decades, the overall objectives of the regime have not changed and this has fuelled continued concern. ${ }^{47}$

Similarly, within the field of international investment law, agreements that relate inter alia to taxes and royalty payments or labour legislation, and which can encompass provisions related to environmental regulation, ${ }^{48}$ have led to concerns that they prioritize the interests of investors over those of host states or environmental

\footnotetext{
${ }^{44}$ Marrakesh (Morocco), 15 Apr. 1994, in force 1 Jan. 1995, available at: http://www.wto.org/english/docs_e/legal_e/06-gatt_e.htm.

${ }^{45}$ A. Palmer, B. Chaytor \& J. Werksman, 'Interactions between the World Trade Organization and International Environmental Regimes', in, S. Oberthür \& T. Ghering (eds), Institutional Interaction in Global Environmental Governance: Synergy and Conflict among International and EU Policies, (The MIT Press, 2006), pp. 181-204.

${ }^{46}$ Esty, n. 3 above. p. 140.

${ }^{47}$ D.C. Esty, 'Free Trade and Environmental Protection', in R.S. Axelrod \& S.D. VanDeveer (eds), The Global Environment: Institutions, Law and Policy, $4^{\text {th }}$ Ed (Sage/CQ Press, 2015), pp. 330-49, at 344.

${ }^{48}$ Tienhaara, n.3 above, p. 102.
} 
protection. ${ }^{49}$ This is arguably symptomatic of the 'competition' of priorities built into the architecture of existing international law and GEG. As Gupta put it, '[t]he incoherence in the policy world reflects the conflicting visions, paradigms, norms and policy instruments chosen by society to deal with specific problems. ${ }^{50}$

Thirdly, the compartmentalization which is sometimes known as 'fragmentation', that is evident within public international law as a whole, also exists within the different subsets of international law and is clearly evident within IEL. It manifests itself in the large number of individual IEL treaty regimes and has led to concern over 'treaty congestion'. ${ }^{51}$ In addition, individual treaty regimes can overlap or conflict not only with each other but also with other branches of public international law. ${ }^{52}$ For example, the International Treaty on Plant and Genetic Resources for Food and Agriculture (ITPGRFA), ${ }^{53}$ the Convention on Biological diversity (CBD), ${ }^{54}$ and the WTO Agreement on Trade-Related Aspects of Intellectual Property Rights (TRIPS) ${ }^{55}$ contain a number of overlapping and inconsistent provisions related to the intellectual property rights associated with genetic resources. ${ }^{56}$ This situation can create concern, confusion

\footnotetext{
${ }^{49}$ Ibid., p. 268.
}

${ }^{50}$ J. Gupta, The History of Global Climate Governance (Cambridge University Press, 2014), p. 207.

${ }^{51}$ D.K. Anton, “"Treaty Congestion” in Contemporary International Environmental Law', in S. Alam,

M.J.H. Bhuiyan, T.M.R. Chowdhury \& E.J. Techera (eds), Routledge Handbook of International Environmental Law (Routledge, 2015), pp. 651-66.

${ }^{52}$ R. Wolfrum \& N. Matz, Conflicts in International Environmental Law (Springer, 2003), p. 7.

${ }^{53}$ International Treaty on Plant and Genetic Resources for Food and Agriculture (Rome), 3 November 2001, in force 29 June 2004, available at: http://www.planttreaty.org/content/texts-treaty-officialversions .

${ }^{54}$ Rio de Janeiro (Brazil), 5 June 1992, in force 29 Dec. 1993, available at: http://www.cbd.int.

${ }^{55}$ Marrakesh (Morocco), 15 Apr. 1994, in force 1 Jan. 1995, available at: http://www.wto.org/english/docs_e/legal_e/27-trips.pdf.

${ }^{56}$ See R. Andersen, Governing Agrobiodiversity: Plant Genetics and Developing Countries (Ashgate, 2013); G.K. Rosendal, 'The Convention on Biological Diversity: Tensions with the WTO TRIPS Agreement over Access to Genetic Resources and the Sharing of Benefits', in S. Oberthür \& T. 
and uncertainty, quite apart from a counterproductive duplication of effort and attrition between institutions. ${ }^{57}$

It must be noted that as a result of some of the negative manifestations of the compartmentalized nature of public international law and its associated institutions, the term 'fragmentation' is frequently used pejoratively. However, in recent years, a growing corpus of academics and practitioners have argued that 'fragmentation' within public international law should not necessarily be regarded in a negative way. ${ }^{58}$ It certainly can be argued that problems related to fragmentation within public international law are not completely intractable as, the Vienna Convention on the Law

Ghering (eds), Institutional Interaction in Global Environmental Governance: Synergy and Conflict among International and EU Policies (The MIT Press, 2006), pp. 79-102; B.J. Condon \& T. Sinha, The Role of Climate Change in Global Economic Governance (Oxford University Press, 2013), pp. 130-53. ${ }^{57}$ See Andersen, ibid; M. Lightbourne, 'The FAO Multilateral System for Plant Genetic Resources for Food and Agriculture' (2009) 30 Washington University Journal of Law and Policy, pp. 465-507 at 466; U. Beyerlin \& T. Marauhn, International Environmental Law (Hart, 2011), pp. 198-9.

${ }^{58}$ M. Andenas \& E. Bjorge, 'Introduction: From Fragmenation to Convergence in International Law', in M. Andenas \& E. Bjorge (eds), A Farewell to Fragmentation: Reassertion and Convergence in International Law (Cambridge University Press, 2015), pp. 1-36, at 2; J. Crawford, Chance, Order, Change: The Course of International Law - General Course on International Law, (The Hague Academy of International Law, 2014), p. 289; C. Greenwood, Unity and Diversity in International Law, in Andenas \& Bjorge (eds), n. 58 above pp. 37-55; F. Biermann, Earth System Governance: World Politics in the Anthropocene (The MIT Press, 2014), pp. 89-92; L.J. Kotzé, 'Fragmentation Revisited in the Context of Global Environmental Law and Governance' (2014) 131 South African Law Journal, pp. 548-82. 
of Treaties (VCLT) $)^{59}$ can assist, a certain degree of convergence may take place, ${ }^{60}$ and also there is the potential for overlap management. ${ }^{61}$

Having said this, it is not the purpose of this article to provide an assessment of the fragmented nature of public international law and its institutions. Fragmentation within public international law here simply serves as an example of the compartmentalized nature of the wide variety of legal and institutional components that ultimately make up GEG.

Instead, the key premise of this article is that legal compartmentalization is reflected in the way lawyers traditionally conduct their legal analysis. Predominantly, legal work focuses on discrete disciplines such as property law, corporate law, criminal law, public international law or specific branches and subsets of international law. ${ }^{62}$ At both the national and international levels it can be observed that there is a general trend for legal analysis to be compartmentalized in manner which corresponds to the way that the law functions in practice. This has led, as a matter of course, to 'micro' legal analysis, as it requires academic lawyers to specialize in and analyze individual disciplines or subdisciplines. ${ }^{63}$ Consequently, research that cuts across and includes aspects of a wide

\footnotetext{
${ }^{59}$ Vienna (Austria), 23 May 1969, in force 27 Jan 1980, available at: http://untreaty.un.org/ilc/texts/instruments/english/conventions/1_1_1969.pdf.

${ }^{60}$ Andenas \& Bjorge, n. 58 above, p. 2.

${ }^{61}$ S. Jinnah, Post-Treaty Politics: Secretariat Influence in Global Environmental Governance (The MIT Press, 2014), p. 5; K. O’Neill, ‘Architects, Agitators and Entrepreneurs: International and
} Nongovernmental Organizations in Global Environmental Politics', in Axelrod \& VanDeveer (eds), n. 47 above, pp. 26-52, at 33.

${ }^{62}$ See J.R. Macey, 'Legal Scholarship: A Corporate Scholar’s Perspective’ (2004) 41 San Diego Law Review, pp. 1759-74; G. Calbresi, 'An Introduction to Legal Thought: Four Approaches to Law and to the Allocation of Body Parts' (2003) 55 Stanford Law Review, pp. 2113-51.

${ }^{63}$ B. Preston, 'Benefits of Judicial Specialisation in Environmental Law: The Land and Environmental Court of New South Wales as a Case Study’ (2012) 29(2) Pace Environmental Law Review, pp. 396440. 
variety of different legal disciplines in a coherent and integrated manner, is inevitably less common. This has an effect on the way that GEG is analyzed; lawyers will naturally tend to approach the subject through the lens of a compartmentalized area of expertise rather than taking into account the full range of component legal disciplines that it is comprised of.

\section{NON-STATE ACTORS AND THE COMPARTMENTALIZATION OF LAW AND LEGAL ANALYSIS}

It is at this juncture that non-state actors will be considered, owing to the important role that they undertake in the development of GEG and the relationship that this has with associated legal analysis. In this context, the term 'non-state actors' will refer to corporations and non-governmental organizations (NGOs). Their involvement with GEG includes the following broad categories: 'governance' roles in the protection of the environment (sometimes referred to as 'delegated authority' ${ }^{64}$ ), influencing the development of IEL, ${ }^{65}$ and developing non-legally binding environmental standards sometimes referred to as 'non-state market driven' (NSMD) initiatives ${ }^{66}$ that are often said to fall under the more general heading of 'transnational environmental regimes' ${ }^{67}$ These different types of interaction have not developed in a coordinated manner and

\footnotetext{
${ }^{64}$ See, e.g., Green, n. 6 above, p. 7.

${ }^{65}$ M.A. Drumbl, 'Actors and Law-Making in International Environmental Law', in M. Fitzmaurice, D.

M. Ong \& P. Merkouris (eds), Research Handbook on International Environmental Law (Edward Elgar, 2010), pp. 3-25, at 11-4.

66 G. Auld, C. Balboa, S. Bernstein \& B. Cashore, 'The Emergence of Non-State Market-Driven (NSMD) Global Environmental Governance: A Cross-Sectoral Assessment', in M.A. Delmas \& O.R.
} Young, Governance for the Environment: New Perspectives (Cambridge University Press, 2009), pp. 183-218, at. 189.

${ }^{67}$ E.g. Pattberg, n. 16 above; P.H. Pattberg \& F. Zelli, Encyclopedia of Global Environmental Governance and Politics (Edward Elgar, 2015); H. Bulkeley, L.B. Andonova, M.M. Betsill, D. Compagnon, T. Hale, M.J. Hoffmann, P. Newell, M. Patterson, C. Roger \& S.D. Vandeveer, Transnational Climate Change Governance (Cambridge University Press, 2014), p. 1. 
are not always easily classified; as such the distinctions between them are often blurred. It can also be noted that the roles of non-state actors within GEG is heavily debated owing to the question of whether their involvement supports or undermines the roles and authority of state actors. ${ }^{68}$

The primary focus in this section is to consider the main characteristics of the three above-mentioned categories of involvement with GEG with a view to understanding the extent to which they correspond with the compartmentalization of environmental law and its associated institutions in practice. Therefore it considers whether the actions and initiatives of non-state actors within these categories support and reinforce that compartmentalization of the law or whether they operate in a manner that looks further by taking into account other law which does not relate to the environment but which ultimately has an impact upon it. It then considers the relationship that these forms of involvement with GEG have with the types of legal analysis that this article is concerned with.

The first category relates to those initiatives in which NGOs are prompted directly or indirectly by governments to undertake specific governance roles. It must be borne in mind that for centuries monarchs had granted charters to non-state organizations to carry out a variety of different purposes. ${ }^{69}$ This tendency has continued in the field of environmental protection and other areas of governance. For example the Royal Society for the Protection of Birds (RSPB) $)^{70}$ is an NGO that developed in the $19^{\text {th }}$ century in Britain and which regularly assists the UK government with specialized knowledge and research. ${ }^{71}$ Also the United States Agency for International Development (USAID),

\footnotetext{
${ }^{68}$ Green, n. 6 above, p. 163; R. Falkner, 'Private Environmental Governance and International Relations: Exploring the Links' (2003) 3(2) Global Environmental Politics, pp. 72-87.

${ }^{69}$ See C. T. Carr, C. T. (ed.), Select Charters of Trading Companies AD 1530-1707. (London: Selden Society, 1913) at p. xi.

${ }^{70}$ The Royal Society of Protection of Birds, available at: http://www.rspb.org.uk .

${ }^{71}$ See for example Churchyard, T., Eaton, M., Hall, J., Millet, J., Farr, A., Cuthbert, R. and Stringer, C. 'The UK's Wildlife Overseas: A Stocktake of Nature in our Overseas Territories' (2014, Sandy, Bedfordshire: RSPB)
} 
the branch of the US government that works in providing civilian aid in foreign countries, has a policy of working with and through NGOs. ${ }^{72}$ Another example is TRAFFIC ${ }^{73}$ which is mandated to produce a comprehensive analytical report of the Elephant Trade Information System (ETIS) data for the CITES Secretariat. ${ }^{74}$ What must be borne in mind however is that it is sometimes the lack of impetus from governments rather than their leadership that provoke NGOs to take on such tasks. For example, the underfunding of international organizations such as the United Nations Environment Programme (UNEP) leaves critical roles that certain NGOs such as the World Resources Institute (WRI) ${ }^{75}$ and Greenpeace ${ }^{76}$ have looked to fill by carrying out functions such as environmental monitoring and policy verification. ${ }^{77}$

What can be observed for the purpose of this analysis is that where non-state actors fill gaps in expertise or undertake specific tasks within specific international environmental law regimes, their work corresponds to the compartmentalized nature of those regimes and will have a tendency to reinforce them.

The second category relates to those instances in which NGOs and corporate actors engage in influencing the processes that develop both hard and soft IEL under the auspices of those regimes themselves. ${ }^{78}$ There are now more opportunities within the

\footnotetext{
${ }^{72}$ See the USAID website, available at: https://www.usaid.gov/partnership-opportunities/ngo .

${ }^{73}$ See TRAFFIC, available at: http://www.traffic.org .

${ }^{74}$ The Convention on Trade in Endangered Species of Wild Fauna and Flora (Washington) (CITES) $3^{\text {rd }}$ Mar. 1972, in force 7 Oct. 1977, 13 ILM 270 (1974) 687.

75 The World Resources Institute (WRI), available at: http://www.wri.org .

${ }^{76}$ Greenpeace, available at: http://www.greenpeace.org.uk .

${ }^{77}$ P. M. Haas, Epistemic Communities, Constructivism, and Environmental Politics, (Routledge, 2016) at p. 222 .

${ }^{78}$ See A. Kiss \& D. Shelton, A Guide to International Environmental Law (Martinus Nijhoff, 2007), p. 66; Drumbl, n. 65 above; J. McCormick, 'The Role of Environmental NGOs in International Regimes', in Axelrod \& Vandeveer (eds), n. 47 above, pp. 92-110.
} 
provisions of IEL for non-state actors to engage. This was called for in Agenda 21, ${ }^{79}$ but is found to be formally enshrined in numerous treaties, including the 1992 Convention for the Protection of the Marine Environment of the North-East Atlantic (OSPAR Convention),${ }^{80}$ the 1992 United Nations Framework Convention on Climate Change (UNFCCC), ${ }^{81}$ and the 1998 United Nations Economic Commission for Europe (UNECE) Convention on Access to Information, Public Participation in Decisionmaking and Access to Justice in Environmental Matters (Aarhus Convention). ${ }^{82}$ More than ever before, environmental and human rights NGOs combine significant professional expertise with stronger financial backing. Along with more economically powerful corporations, they engage in the processes of law and norm creation on the international stage through lobbying, agenda-setting and petitioning. ${ }^{83}$

In this category too, it can be observed that where non-state actors become involved, within the permitted opportunities that are provided for by specific regimes they tend to reinforce the existing compartmentalization of IEL as they are inevitably operating within the confines of those regimes.

The third category of involvement relates to non-state actor initiatives to develop nonlegally binding environmental standards with a view to influencing the conduct of

\footnotetext{
${ }^{79}$ Section III of Agenda 21 provides for the strengthening role of major groups, see United Nations Conference on Environment and Development, Rio de Janeiro (Brazil), 3-14 June 1992, UNCED Report, A/CONF.151/26/Rev.1 (vol. I) (1993), available at: https://sustainabledevelopment.un.org/content/documents/Agenda21.pdf.

${ }^{80}$ Paris (France), 22 Sept. 1992, in force 25 Mar. 1998, available at: http://www.ospar.org; Art. 11(1).

${ }^{81}$ New York, NY (US), 9 May 1992, in force 21 Mar. 1994, available at: http://unfccc.int; Art. 7(6).

82 Aarhus (Denmark), 25 June 1998, in force 30 Oct. 2001, 2161 UNTS 447, available at: http://www.unece.org/env/pp/welcome.html; Art. 10(5).

${ }^{83}$ Drumbl, n. 65 above, pp. 11-4. However, it must be acknowledged that both corporations and NGOs can and often do also influence decision-making that affects the environment through non-formal means.
} 
businesses, consumers and at times governments themselves. ${ }^{84}$ These can involve corporate actors, NGOs or the two working in tandem on NSMD initiatives. Examples include: the standards of the AccountAbility 1000 standards,${ }^{85}$ the standards developed by the International Organization for Standardization (ISO), ${ }^{86}$ the certification system of the Forest Stewardship Council (FSC), ${ }^{87}$ the Carbon Disclosure Project (CDP), ${ }^{88}$ the Global Reporting Initiative (GRI), ${ }^{89}$ and Walmart's Sustainability Index. ${ }^{90}$

These approaches represent ad hoc 'governance from below' responses, which are gaining considerable momentum, but which are regarded by some as 'too timid a remedy ${ }^{91}$ for global challenges that may require robust and orchestrated responses from the majority of states. However, regardless of their overall potential for impact, NSMD initiatives represent a particular type of leadership, which is pertinent to the development of 'macro' legal analysis within scholarship relating to GEG. This is because some of the NSMD schemes show an understanding that encompasses not only the failings of environmental law but also the importance of other legal disciplines, such as trade law and corporate law, to environmental outcomes. For example, the FSC certification scheme recognizes that the absence of trade law that would halt trade in certain types of timber and responds with measures that de facto create trade rules for

\footnotetext{
${ }^{84}$ See Green, n. 6 above, p. 7; see also B.J. Richardson, 'Socially Responsible Investing for
} Sustainability: Overcoming its Incomplete and Conflicting Rationales' (2013) 2(2) Transnational Environmental Law, pp. 311-38, at 316.

${ }^{85}$ Available at: http://www.accountability.org/about-us/index.html.

${ }^{86}$ Available at: http://www.iso.org/iso/home.html.

${ }^{87}$ Available at: https://ic.fsc.org.

${ }^{88}$ Available at: https://www.cdp.net.

${ }^{89}$ Available at: https://www.globalreporting.org.

${ }^{90}$ Available at: http://corporate.walmart.com/article/sustainability-index.

${ }^{91}$ M.C. Lemos \& A. Agrawal, 'Environmental Governance and Political Science', in Delmas \& Young (eds), n. 66 above, p. 83. 
participants of the scheme. ${ }^{92}$ Similarly, it can be argued that the GRI accounting standards for corporations respond to limitations within corporate law relating to national accounting standards and require participants to produce sets of comprehensive environmental accounts. ${ }^{93}$

In the cases of both the FSC certification scheme and the GRI accounting standards, the initiatives look beyond an approach that corresponds with a simple 'micro' legal analysis of the environmental law to consider the root causes within other areas of law that are directly associated with the specific harms to the environment concerned. Whilst the approaches of the FSC and the GRI cannot be said to amount to the type of 'macro' legal analysis that this article puts forward, they could be regarded as precursors to that type of approach.

It is clear that non-state actors play vital roles in the development of GEG. However, much of their activity takes place within the compartmentalized components of GEG and as such they often reinforce that compartmentalization through their practices and through the 'micro' legal analysis that they undertake to engage in those processes. By the same token, there are important exceptions to this, such as certain NSMD schemes which arguably play an important role in leading the international community towards cross-cutting approaches to legal analysis and which bear some of the characteristics of the type of 'macro' legal analysis this article advocates.

\section{THEORETICAL ARGUMENTS RELATING TO THE USE OF 'MACRO' LEGAL ANALYSIS.}

Having discussed the compartmentalized nature of both the law itself and legal analysis related to the constituent elements of GEG, it is necessary to consider the type of legal

\footnotetext{
${ }^{92}$ G. Auld, Constructing Private Governance: The Rise and Evolution of Forest, Coffee, and Fisheries Certification, (Yale University Press, 2014), p. 2; B. Cashore, G. Auld \& D. Newsom, Governing Through Markets: Forest Certification and the Emergence of Non-State Authority (Yale University Press, 2004).

${ }^{93}$ See GRI n. 89 above.
} 
analysis that would assist lawyers and policy makers in developing better informed strategies for GEG in the future. This section reviews theoretical arguments for renewed approaches to legal analysis and the development of GEG. These arguments assist in developing a set of criteria for the design of 'macro' legal analysis that could enhance our understanding and development of GEG.

The first critique relates to the exclusionary nature of contemporary public international law. For decades, some international lawyers have complained that international law creates a system of governance that addresses states without directly addressing the range of other actors that are involved in decision-making and who may influence decisions and outcomes in the international sphere. For example, in 1989, Sands commented on the traditional form of public international law by stating that:

[t]he traditional model poses two fundamental problems. First, states have generally proved unwilling to exercise their right of "guardian-ship" over the global environment. Second, the notion of sovereignty which underlies the current regime poses insurmountable obstacles when the problems to be addressed are transnational in scope. ${ }^{94}$

In the same article he later asserted that:

$[\mathrm{u}]$ ntil international law moves away from the view that international society comprises a community of states, and comes to encompass the persons (both legal and natural) within those states, it will not be able to provide even the most elementary framework for the protection of the environment. ${ }^{95}$

A reading of that analysis today possibly belies certain achievements in the protection of the environment that have been made possible as a result of the existing system of international law. However, the fact that the international community, with its continued reliance on a state-centred form of international law, still struggles to effectively address the impact that non-state as well as state actors have upon the

\footnotetext{
${ }^{94}$ P. Sands, 'The Environment, Community and International Law' (1989) 30(2) Harvard International Law Journal, pp. 393-420, at 399.

${ }^{95}$ Ibid., p. 393.
} 
environment is a testament to its continued validity. ${ }^{96}$ As such, it can be argued that if the international community is to develop a system of law at the international level that responds directly to the rights, duties and responsibilities of both state and non-state actors, a form of 'macro' legal analysis that takes into account all relevant law and quasi-legal rules could greatly assist.

Second, there is increasing interest in the multifaceted manner in which solutions to environmental issues can be found. These include not only the direct measures that states implement in terms of conservation and pollution control, but in addressing a range of ancillary laws and rules that do not have the appearance of being directly related to the environment, but which can ultimately act as the 'drivers' and 'root causes' of environmental degradation. For example, Daniel Bodansky states that:

[i]f international environmental law is to address not merely the surface manifestations but the root causes of environmental degradation, then our understanding of what constitutes an environmental issue must grow to encompass economic, social, and trade policy. Indeed, if, as some claim, everything is interconnected, then everything becomes an environmental problem. For now, however, this kind of integration is still more of an aspiration than a reality. ${ }^{97}$

Whilst Bodansky still recognizes the 'considerable sense' in treating IEL as a discrete field of study, ${ }^{98}$ the admission that it frequently focuses on the symptoms of environmental degradation as opposed to the 'root causes', indicates a need to pursue a wider approach. This suggests that we need a type of legal analysis broad enough in scope but incisive enough in method to identify and highlight the underlying causes of environmental degradation within the global legal architecture, and then to assess them in their entirety.

\footnotetext{
${ }^{96}$ E.g. B.J. Richardson \& B. Sjåfell, 'Capitalism, the Sustainability Crisis, and the Limitations of Current Business Governance', in B.J. Richardson \& B. Sjåfell, n. 3 above, pp. 1-34 at 18-9.

${ }^{97}$ Bodansky, n. 1 above, p. 11.

${ }^{98}$ Ibid.
} 
Third, there has been considerable focus on the issue of 'fragmentation' in international law, ${ }^{99}$ both academically and institutionally. ${ }^{100}$ In response, Koskenniemi has suggested that the international community is bound by regimes which are often at odds or even competing with each other. He states that what is required is 'cosmopolitanism', which he describes as:

a professional sensibility that feels at home in all regimes, yet is imprisoned in none of them. This would be what cosmopolitanism can be today: the ability to break out and connect, participate in the politics of regime definition by narrating regimes anew, giving voice to those not represented in the regime's institutions. ${ }^{101}$

It can be argued that to achieve the type of 'cosmopolitanism' that Koskenniemi suggests, a specific type of analysis combined with a corresponding form of training that encompasses the diversity of regimes, would need to be developed. 'Macro' legal analysis could assist in achieving this as it could lead to a professional sensibility that takes into account all relevant legal and quasi-legal regimes. Additionally, in the short term 'macro' legal analysis could assist in generating strategies to resolve some of the current challenges of fragmentation in international law.

Fourth, the comments made in this section relating to the type of legal analysis needed to assist in the development of effective strategies for GEG have some clear parallels with the concern raised by Fisher et al., that legal scholarship relating to environmental law commonly disregards a wide range of factors, both legal and non-legal, that ultimately affect it. ${ }^{102}$ They stress that, notwithstanding the methodological challenges

\footnotetext{
${ }^{99}$ M. Andenas \& E. Bjorge, in Andenas \& Bjorge (eds) n. 58 above, p. 2.; ILC, n. 43 above,.

${ }^{100}$ M.A. Young, Trading Fish, Saving Fish: The Interaction between Regimes in International Law,

(Cambridge University Press, 2012), pp. 8-16; Carlane, n. 43 above, pp. 456-62; J. Pauwelyn, Conflict

of Norms in Public International Law: How WTO Law Relates to Other Rules of International Law

(Cambridge University Press, 2003).

${ }^{101}$ Koskenniemi, n. 4 above, p. 360.

${ }^{102}$ E. Fisher, B. Lange, E. Scotford \& C. Carlane, 'Maturity and Methodology: Starting a Debate about Environmental Law Scholarship' (2009) 21(2) Journal of Environmental Law, pp. 213-50; see also J.M
} 
involved, the failure to include relevant factors within legal scholarship can lead to 'intellectual blind spots'. ${ }^{103}$ Whilst their analysis focuses on scholarship in the field of environmental law and not legal analysis relating to the understanding and development of GEG per se, there are clear overlaps with the argument developed in this article.

Therefore, it is argued that a carefully designed form of 'macro' legal analysis could assist in addressing some of the problems within the development of GEG that have been identified through key theoretical arguments of recent years. As such it would have the potential to contribute to the process of identifying solutions that overcome the dysfunctions within the existing forms of GEG and assist in laying the foundations for coherently designed reform options.

Finally, the approach of seeking to incorporate all relevant factors within an overall analysis also has significant parallels with the approach adopted by the Earth System Governance Project, based in Lund (Sweden). ${ }^{104}$ The Earth System Governance Project has brought many experts together to focus on five particular analytical problems concerned with GEG. These are: the overall architecture of earth system governance; agency beyond the state and of the state; the adaptiveness of governance mechanisms and processes as well as their accountability and legitimacy; and modes of allocation and access in earth system governance. ${ }^{105}$

What is important for the purposes of this discussion is that the Earth System Governance Project tackles GEG from a perspective that stresses the importance of

Balkin, 'Understanding Legal Understanding: The Legal Subject and the Problem of Legal Coherence' (1993) 103 The Yale Law Journal, pp. 105-76, at 138; O. Pedersen, 'Modest pragmatic lessons for a diverse and coherent environmental law' (2013) 33(1) Oxford Journal of Legal Studies, pp. 103-131; D. Owen \& C. Noblet, 'Interdisciplinary Research and Environmental Law' (2014) Ecology Law Quarterly, pp. 887-938; Gavin Little, 'Developing environmental law scholarship: going beyond the legal space' (2016) 36(1) Legal Studies, pp. 48-74.

${ }^{103}$ Fisher et al., Ibid, p. 241.

${ }^{104}$ Biermann, n. 58 above.

${ }^{105}$ Ibid. pp. 9-10. 
including expertise from a range of social sciences in addition to that of natural science. As such, it is arguably symptomatic of a move towards analytical frameworks that encompass a wide-range of relevant factors in the development of reform recommendations. It is argued that the logic of adopting a broad approach to the analysis of issues relating to GEG, could be adopted within analysis of the law through a carefully designed form of 'macro' legal analysis.

\section{A METHODOLOGY FOR THE USE OF 'MACRO' LEGAL ANALYSIS}

In order for 'macro' legal analysis to provide a broader understanding and inform the future development of GEG, it is suggested that the methodology needs three core elements.

The first is that it should encompass the different legal disciplines that are applicable to, or have the potential to affect, the aspect of the environment concerned. ${ }^{106}$ It would be necessary to analyze not only national and international environmental law but also potentially other areas of law, such as trade, corporate, banking, and tax law. Additionally, that analysis would need to take place alongside assessments of the associated initiatives by non-state actors, which create governance structures such as accountability mechanisms and certification schemes. ${ }^{107}$

The second is that in addressing the different legal disciplines that are applicable to the environmental issue or that have the potential to affect it, the elements of the law that are found to comprise the 'root causes' or 'drivers' 108 of environmental harm need to be properly identified. This may require an analysis that challenges underlying

\footnotetext{
${ }^{106}$ Bodansky, n.1 above, p. 11.

${ }^{107}$ See, e.g., GRI, n. 89 above; Auld, n. 92 above, p. 2; Cashore, Auld \& Newsom, n. 92 above; FSC, n. 98 above; Pattberg, n. 16 above.

${ }^{108}$ Bodansky, n. 1 above, p. 10.
} 
assumptions relating to purposes of aspects of the law, and the way that it and its associated institutions operate. ${ }^{109}$

The third is that in considering the reform of law and associated institutions, the working relationships between different regimes need to be taken into account so that overall efficiencies in terms of cost and administration can be accomplished. ${ }^{110}$ This means that in the process of re-designing legal architecture, there should be both an overarching environmental goal that can be integrated within the objectives of all institutions and appropriately constructed regimes to ensure that the institutions operate in a streamlined manner. ${ }^{111}$ Increasingly, calls are made for 'greater attention to crossscale issues in efforts to govern the environment' 112 and 'more collaborative forms of

${ }^{109}$ Examples could include directors' duties within the company law of all jurisdictions around the globe, see Turner, n. 35 above, pp. 36-50; also aspects of the trade rules under the GATT, see Esty, n. 3 above, p. 140.

${ }^{110}$ Literature on the re-design of international environmental institutions includes: K. Bosselmann, Earth Governance: Trusteeship of the Global Commons (Edward Elgar, 2015) pp. 257-67; Desai, n. 5 above; Anton, n. 51 above,; N. Goetyn \& F. Maes, 'The Quest for a World Environment Organization: Reflections on a Failing Debate and Input for Future Improvement', in P. Martin, L. Zhiping, Q. Tianbao, A.D. Plessis, Y.L. Bouthillier \& A. Williams (eds), Environmental Governance and Sustainability (Edward Elgar, 2012), pp. 233-247; S. Charnovitz, 'Towards a World Environment Organization: Reflections on a Vital Debate', in F. Biermann \& S. Bauer (eds), A World Environment Organization: Solution or Threat to Effective International Environmental Governance? (Ashgate, 2005), pp. 173-93.

${ }^{111}$ Koskenniemi, n. 4 above, p. 360; Certain authors argue for the establishment of a 'grundnorm', or in other words a goal that would bind the actions of international environmental actors and institutions. See, e.g., R.E. Kim \& K. Bosselmann, 'International Environmental Law in the Anthropocene: Towards a Purposive System of Multilateral Environmental Agreements' (2013) 2(2) Transnational Environmental Law, pp. 285-309.

${ }^{112}$ M. C. Lemos \& A. Agrawal, 'Environmental Governance and Political Science’ in Delmas \& Young (eds), n. 67 above, p. 73. 
governance ${ }^{113}$ that engage effectively with the range of different institutions that can have an impact upon environmental governance. ${ }^{114}$

Taking the aforementioned elements into account, it is suggested that the main components of such a methodology should be based on the following stages:

1. An analysis of the desired outcome for the environmental issue concerned, based on scientific evidence. ${ }^{115}$ There is a growing demand for law and policy relating to GEG to be aligned with what have become known as 'planetary boundaries'. ${ }^{116}$ Rockström and colleagues have defined such boundaries in relation to climate change, biodiversity loss, the nitrogen cycle, the phosphorous cycle, stratospheric ozone depletion, ocean acidification, global freshwater use, land use change, atmospheric aerosol loading, and chemical pollution. They suggest that if specific thresholds within those spheres are crossed, the results could lead to extreme negative consequences for humanity. Some authors also refer to these thresholds as 'earth system boundaries';117

\footnotetext{
113 Ibid.

${ }^{114}$ Winter, n. 17 above, p. 2.

${ }^{115}$ See Centre for Governance and Sustainability, University of Massachusetts Boston, 'Summary

Report - Workshop on International Environmental Governance: Grounding Policy Reform in Rigorous Analysis’'(June 27-28, 2011, Bern, Switzerland) 11, available at: http://dev.environmentalgovernance.org/wp-
} content/uploads/2011/06/12.058_CGS_report_single_v10.pdf ; A. Campbell Keller, 'Science in Environmental Policy: The Politics of Objective Advice’ (The MIT Press, 2009); also P.M. Haas, ‘Science Policy for Multilateral Environmental Governance’ (Feb. 2012) available at: http://www.crcresearch.org/files-crcresearch/File/haas_02.pdf .

116 J. Rockström, et al., ‘A Safe Operating Space for Humanity’ (2009) 461 Nature, pp. 472-5.

${ }^{117}$ Biermann n. 58 above, p. 32. 
2. The identification of all legal provisions (whether that be national or international) that can have an influence (both positive and negative) on the environmental issue concerned; ${ }^{118}$

3. An overview analysis of all legal aspects (whether that be national or international) that can have an influence (both positive and negative) on the environmental issue with a view to understanding, inter alia, their rationale and the extent to which they contain 'root causes' or 'drivers' of environmental degradation; ${ }^{119}$

4. An analysis of all non-legally binding governance initiatives relating to the environmental issue, such as codes of conduct, eco-labeling schemes, certification schemes and corporate reporting schemes. This analysis should include an examination of the lacunae or problematical features in the law that their existence attempts to redress; ${ }^{120}$

5. An analysis of the possible legal reforms that would be required to 'streamline' each of the legal disciplines concerned to ensure that they predispose all of the actors involved to the accomplishment of the 'environmental outcomes' identified in stage 1. This should include the reforms needed to respond effectively to the problematical features or lacunae in the law identified in stages 3 and 4 above;

6. An assessment of the steps, including institutional reform, that would be required to accomplish the aims in stage 5 over specific timescales.

\footnotetext{
${ }^{118}$ Such areas of law may for example include: company law, tax law, investment law, banking law, trade law, environmental law and international environmental law.

${ }^{119}$ E.g., if it was clear that company law had an impact, it may be pertinent to analyze the specific aspect of corporate law such as 'directors' duties' that was having an effect on the outcome for the aspect of the environment concerned. See, e.g., Richardson \& Sjåfell, n. 3 above.

${ }^{120}$ E.g., the initiatives of the GRI and FSC.
} 


\section{CHALLENGES IN THE APPLICATION OF 'MACRO' LEGAL ANALYSIS}

The type of 'macro' legal analysis that is proposed here raises numerous challenges. ${ }^{121}$ Two of the broader issues will be considered. These are firstly, the relationship that 'macro' legal analysis should have with 'micro' legal analysis; and secondly, the type application that it could have to different aspects of GEG.

Both 'micro' and 'macro' legal analysis have their strengths and weaknesses. As 'micro' legal analysis is required to develop the type of understanding of law that is required for legal practice, it has understandably dominated and become deeply embedded at all levels. ${ }^{122}$ However, for research relating to GEG at least, a healthy balance should be sought between 'micro' and 'macro' legal analysis. Naturally, 'macro' legal analysis would not provide the same level of detail as 'micro' legal analysis, but on the other hand, 'micro' legal analysis will inevitably not provide the more synoptic insights that 'macro' legal analysis could offer. It is therefore argued that the two forms of analysis should inform and strengthen each other in a mutually reinforcing relationship that ultimately would have the capacity to provide the best possible guidance for law and policy makers.

'Macro' legal analysis could be applied within GEG in numerous ways. If, as some assert, international lawyers should see themselves as 'architects of global

\footnotetext{
${ }^{121}$ E.g., questions for further thought include: How would it be possible to determine what the desired outcome for the environment should be, based on scientific evidence? How would this type of analysis be linked to other 'non-legal' policy considerations in the development of renewed strategies for global environmental governance?

${ }^{122}$ C.B. Picker 'Comparative Law as an Engine of Change for Civil Procedure', in C.B. Picker \& G.I. Seidman (eds), The Dynamics of Civil Procedure: Global Trends and Developments (Springer, 2016), pp. $45-59$ at 47.
} 
governance', ${ }^{123}$ then 'macro' legal analysis may assist in equipping them to carry out that role. Some contend that the international community is at a crucial juncture in the development of GEG. For example, Ivanova states that, '[t]today's debates on reforming [GEG] stand at a cross-roads strikingly reminiscent of the one facing the system's original architects in the lead-up to the 1972 Stockholm Conference. ${ }^{124}$ It is certainly the case that recognition of the need for further reform has been voiced by the leadership of UNEP. Achim Steiner, the former Executive Director of UNEP, has emphasized the evolving role of the UN and specifically the need for further reforms to ensure that UNEP continues to adapt to the challenges that the international community faces. ${ }^{125}$ The type of perspective that 'macro' legal analysis provides could possibly assist in these processes.

Whilst this article has focused on governance at the global level, 'macro' legal analysis can also be applied at the project level. It can be used to identify the legal architecture that plays a part in the relationships between industrial projects and the environment and affected communities. In that context, 'macro' legal analysis might promote an examination of a project with regard to, inter alia, property law, the rights of indigenous groups, corporate law, banking law, investment law, administrative law, tax law, human rights law, as well as environmental law. ${ }^{126}$

Finally, although 'macro' legal analysis could be applied to a wide variety of challenges within the field of GEG, it could possibly have particular usefulness in helping to address those problems that, in part at least, are exacerbated through the shortcomings of extant approaches under the Westphalian system of international law. Climate change is representative of that category as it is a particularly complex problem and an

\footnotetext{
${ }^{123}$ K.W. Abbot, 'Towards a Richer Institutionalism for International Law and Policy’ (2005) 1(1-2)

Journal of International Law and International Relations, pp. 9-34, at 11.

${ }^{124}$ M. Ivanova, 'UNEP in Global Environmental Governance: Design, Leadership, Location’ (2010)

10(1) Global Environmental Politics, pp. 30-59, at 53.

${ }^{125}$ A. White of the Tellus Institute, Interview with Achim Steiner of UNEP (Feb. 2105), available at: http://www.greattransition.org/publication/uniting-nations-the-un-at-a-crossroads.
}

${ }^{126}$ See, e.g., Turner, n. 3 above. 
extremely difficult challenge for the international community to confront. It is therefore possible that 'macro' legal analysis could prove to be a useful tool to inform the development of the legal and policy approaches that are designed to tackle it.

\section{CONCLUSION}

This article has sought to make the central argument that 'macro' legal analysis can assist in our understanding and development of the legal and quasi-legal components of GEG. It has made the case that this form of analysis has the potential to provide an important perspective and understanding for lawyers and policymakers to draw upon in developing reform options. Owing to the broad perspective that it can provide, such analyses could potentially prove equally useful to those from other disciplines such as the political sciences, economics and ecology.

However, the assertions made in this article have wider implications. If 'macro' legal analysis can play an important role in the way that we understand and develop GEG, there are major questions regarding the way that we train the lawyers who will become the discipline's architects and advisers. Arguably, the skills they require are not the same as the 'micro' level skills that practitioners need to develop.

It can therefore be concluded that, at the masters and $\mathrm{PhD}$ levels at least, legal training should include a grounding in the wide range of legal disciplines that impact upon GEG, including an understanding of the roles of relevant international institutions as well as the different types of quasi-legal initiatives undertaken by non-state actors. Such training would not only sensitize aspiring scholars and policy advisers to many of the legal factors that are integral to determining environmental outcomes but would also provide them with a foundation to develop research in GEG, using a 'macro' legal analytical approach.

Such an approach is not consistent with the orthodox methods that lawyers commonly adopt and therefore can seem to be either counter-intuitive or simply outside of the scope of the role that they should undertake. However, the challenges that GEG present to the international community are extraordinary ones that do not always respond to traditional methods of legal problems solving. Therefore, it is necessary for the legal 
community to further the development of logical and evidence-based strategies. This may include adopting methods such as 'macro' legal analysis to carry out functions for which 'micro' legal analysis is less well suited. 